\title{
BOARD OF DIRECTORS AND TOP MANAGEMENT TEAM. CEO RELATIVE POWER AND FINANCIAL RETURNS IN BRAZIL
}

\section{1- Beatriz Schalka*}

Mestre em Gestão Internacional da Fundação Getúlio Vargas (FGV-EAESP), Brasil. bschalka@gmail.com

\section{2- Gilberto Sarfati}

Doutor em Ciência Política pela Universidade de São Paulo (USP-SP), Brasil.

Professor do Programa de Mestrado Profissional em Gestão Internacional da Fundação Getúlio Vargas (FGV-EAESP), Brasil. gilberto. sarfati@fgv.br

http://lattes.cnpq.br/3185399782638718

Diego Maganhotto Coraiola - Editor Geral
Editor responsável pela submissão:
Edson Ronaldo Guarido Filho.

Artigo analisado via processo de revisão duplo cego (Double-blind). 


\section{BOARD OF DIRECTORS AND TOP MANAGEMENT TEAM. CEO RELATIVE POWER AND FINANCIAL RETURNS IN BRAZIL ${ }^{1}$}

\section{ABSTRACT}

This article investigates if companies with a stricter control and monitoring system perform better than others in Brazil. The works compares 116 companies in respect to the their independence level between top management team and board directors- being that measured by four parameters, namely, the percentage of independent outsiders in the board, the separation of CEO and chairman, the adoption of contingent compensation and the percentage of institutional investors in the ownership structure - and their financial return measured in terms return on assets (ROA) from the latest Quarterly Earnings release of 2012 . Two variables (percentage of outside directors and percentage of institutional investor ownership) are significant in the regression. This paper has provided evidences that the increase in the formal governance structure trough outside directors in the board and ownership by institutional investor might actually lead to worse performance.

\section{Keywords}

Corporate governance, control, board of directors.

\section{CONSELHO DIRETOR E EQUIPE DE ALTO NÍVEL ADMINISTRATIVO. PODER RELATIVO DO CEO E RETORNOS FINANCEIROS NO BRASIL}

\section{RESUMO}

Este artigo investiga se as empresas com um controle mais rigoroso de monitoramento performam melhor que outras empresas. O artigo compara 116 empresas no que diz respeito ao seu nível de independência entre a equipe de alto nível administrativo e o conselho diretor medida por quatro parâmetros: a percentagem de conselheiros independentes no conselho, a separação de CEO e presidente, a adoção de compensações contingentes e a percentagem de investidores institucionais na estrutura de propriedade - e seu retorno financeiro medido em termos retorno sobre ativos (ROA) em relação aos resultados trimestais de 2012 . Duas variáveis (percentual de diretores externos e percentual de participação de investidores institucionais) são significativos na regressão. Este trabalho fornece evidências de que o aumento da governança através da estrutura formal fora do conselhor diretor e apropriação por parte dos investidores institucionais pode realmente levar a pior performance financeira.

\section{Palavras-Chave}

Governança corporativa, controle e conselho diretor. 


\section{Introduction}

Derived from the separation of ownership and control, the principal-agent has arisen as an important issue that organizations face nowadays (Fama \& Jensen, 1983). According to the agency theory, it relates to the fact that shareholders from corporations must nominate someone who will supposedly behave on their best interest and, therefore, act in such a way that maximizes shareholders' value (Jensen \& Meckling, 1976). However, this situation triggers a number of issues, such as information asymmetry, different risk preferences and wrongly intended behavior.

Bearing in mind this critical situation, corporations have started to find ways to solve or attenuate this problem. The field of Corporate Governance represents the ultimate attempt to protect shareholders' interest from CEOs biased and wrongly intended behavior. Over the last decade corporate governance topics have received enormous attention due to a number of governance failures, including top leading companies in their segments, such as Enron and Parmalat (Cai, Liu, \& Qian, 2002; Marcel \& Cowen, 2014).

In Brazil several studies show a growing interest and concern on Corporate Governance such as Pinto and Lean (2013) on ownership concentration and board compensation, Okimura, Silveira and Rocha (2007) on the relationship between control and ownership structure, value and performance of Brazilian public companies listed in the São Paulo Stock Exchange and Caixe and Krauter (2013) on ownership and control concentration and corporate market value.

Derived from corporate governance failures, and supported by theoretical background, many firms have engaged in governance structure systems based on controlling and monitoring, aiming at protecting shareholders 'interests. However, as Langevoort (2001) argues, this model of corporate governance has been characterized as largely deficient.

Therefore, the aim of this paper is to examine the relationship between governance structures perceived to be stricter - in respect to the level of control and monitor - and the financial return of the companies. The underlying understanding is that not necessarily more sophisticated governance structures in regard to control will lead to higher financial return, given that some other aspects, such as collaboration and trust among the top management team and the board of directors although crucial, are still neglected (Zahra \& Pearce, 1990; Dalton, Hitt, Certo, \& Dalton, 2007).

This article argues that companies with a more rigid corporate governance structure in respect to control and monitor do not necessarily outperform companies with less rigid corporate governance structure. Best corporate governance practices published in the primers of Brazilian Securities and Exchange Commission (Comissão de Valores Mobiliários, or CVM) and the Brazilian Corporate Governance Institute (Instituto Brasileiro de Governaça Corporativa, or IBCG) promote board independence as much as possible, as a way to increase the effectiveness of its governance mechanism.

The method applied in this paper consists on comparing 116 Brazilian companies in respect to the their independence level between top management team and board directors- being that measured by four parameters, namely, the percentage of independent outsiders in the board, the separation of CEO and chairman, the adoption of contingent compensation and the percentage of institutional investors in the ownership structure - and their financial return measured in terms return on assets (ROA) from the latest Quarterly Earnings release of 2012.

This paper is structured in the following manner: first, it provides an extensive literature review on the relevant topics, namely, agency theory, corporate governance, board of directors and the concept of CEO relative power. Secondly, it explains the methodology and how the data is constructed. Presented that, the paper addresses the results obtained from the data gathering, being the latter structured in three sub sections: sample overview, regression analysis with the developed scale for this paper, and finally regression analysis with the independent variables being transformed into dummy variables. Lastly, conclusions are drawn, as well as the limitations and suggestion for future researches.

\section{Literature Review}

\subsection{The Agency Problem}

Agency costs has been an important concern in Business Administration in a long time (Wilson, 1968; Ross, 1973). The separation of ownership and control has deeply affected the paradigm of owner-manager, being it substituted by what we know as professionalized management. Therefore, 
according to Fama (1980), the agency problem arises exactly from the separation of two functions usually attributed to the entrepreneur, namely risk bearing and management.

The first element to understand the principal-agent problem is grounded on the arena of contractual relationships. As Fama and Jensen (1983) explains, "an organization is the nexus of contracts, written and unwritten, among owners of factors of production and customers" (Fama \& Jensen, 1983, p. 302). Namely the "rules of the game" specify the rights of each agent in the organization, establish the performance criteria against which individuals will be appraised and set up the expected payoff for a combination of firm value and observed behavior of each agent.

However, as Fama and Jensen (1983) argue, the main source of agency problems arises exactly because contracts cannot be costless written and enforced. In this context, agency costs refer to the lost associated with structuring, monitoring and bonding a set of contracts between agents with conflicting interests. Therefore, as not all the potential situations that may occur when managing a company can be anticipated and included in the contract between managers and owners, there is the inevitable principal-agent problem that must to be solved via different mechanism, such as Corporate Governance instruments (Jensen \& Meckling, 1976).

Within this scope, Hart (1995) explains in details that there are three costs that are particularly relevant. First, there is the cost of thinking about all the different eventualities that can occur while the contract is still in vigor. Second, there is the cost of negotiating with others about the contracts. Third, there is the cost of translating contracts into legal objects that could enforced by a third party in the case of a dispute. Therefore, in his understanding, corporate governance is merely "mechanisms for making decisions that have not been specified in the initial contract" (Hart, 1995, p. 680).

From the perspective that there are innumerous conflicts between the two characters in the context - principal and agent - some researchers have grounded agency theory on instruments that align interests. Jensen and Meckling (1976) understanding is that any managerial behavior can be determined by the incentives provided to the managers. In other word, the authors believe that simple alterations in the wage and incentive package are sufficient to resolve any problem regarding appropriate and expected behavior from the management team. Yet, this theory does not blind closely with reality, as individuals cannot be narrowed down to an economic perspective, and social, political, psychological spheres must also be considered (Daily, Dalton, \& Canella, 2003).

According to Eisenhardt (1989), agency theory is concerned with solving two issues. First, it focuses on the fact that the principal cannot closely verify what the agent is doing. The second issue relates to the fact that agent and principal have different risk preferences, and therefore the optimal solution for one might not represent the optimal solution for the other. Therefore, as can be noticed by the nature of the issues, this perspective considers that the most important element is determining the optimal contract between principal and agent. This optimal contract varies according to risk aversion and information level between principal and agent.

However, although mathematically correct in many cases, there are a wide range of shortcomings that is triggered from aligning interests through mainly financial incentives. Firstly, very often there is not a direct and straight link between managers' effort and the firm performance. In other words, as Shavell (1979) suggests that when there is a noise between manager's marginal product - the expected value from his/her actions cannot be traced unambiguously and costlessly to the manager's actions - risk adverse managers will always choose to share part of the uncertainty in the evaluation of his performance with the firm's risk bearers.

Secondly, CEO's expected behavior cannot always be correctly translated to numbers. Positivist agency theory argues that contracts must be outcome-based, in the sense that executives are compensated according to observed level of outcome. However, as Eisenhardt (1989) explains, there are many pitfalls when this theory is mirrored to the reality. Executives of modern corporations must perform in different directions (socially, financially, environmentally, etc.) and therefore a single measure might be misleading regarding his expected behavior. Additionally, the programmability of the agent's task influence the effectiveness of outcome based contracts. The relationship between programmability and outcome based contract effectiveness is directly proportional, in the sense that the higher the programmability of a specific task, the more effective will be aligning interest trough outcome-based contracts. Bringing this theory to reality, it is comprehensible that outcome-based contracts will not be effective to shape CEOs' behavior, as their task has an extremely low level of programmability and depends on a myriad of aspects, such as world economy, business environment, etc. 
Aiming at overcoming all the listed issues related to aligning interests through incentive packages, the third key element of agency theory is observation. The principal, in this context, wants to understand whether the agent is shrinking (referring to the problem of moral hazard, in which managers lack of effort is observable) or striving to achieve positive outcomes. The problem, however, is that the principal will never be able to closely observe the agent so that he/she will feel forced to act according to expected behavior. In other words, he/she can find a way to masked efforts and continue with a shrinking attitude. Therefore, as Eisenhardt (1989) proposes, principals can invest in information systems, such as budgeting, reporting, etc, to increase vigilance on the agent. Saltaji (2013) reviewing the recent literature recognizes five solutions to agency problems: a)managerial labor market; b) corporate boards; c) corporate financial policy; d) block holders and institutional investors; e) market for corporate control; f) managerial remuneration. On the other hand, Lan and Heracleous (2010) argue that the growing body of literature proposing solutions to mitigate agency problems has failed to support their efficacy.

\subsection{Corporate Governance}

Based on the assumption that managers are self-interested and would deviate whenever possible from actions that benefit residual claimants, economists have struggled to understand how organizations have managed to survive despite the poor and dishonest management. The first plausible suggestion to solve this problem was presented by Jensen and Meckling (1976), who distinctively proposed the initial concept of corporate governance.

The amount of corporate governance research has increased dramatically during the last decade: searching for this term in the Social Sciences Research Network leads to more than 10.300 results. This ultimately shows the increasing relevance that both academic and managerial arenas give to the field corporate governance. The increasing importance of corporate governance is noted even in several emerging markets (Claessens \& Burcin, 2013). Daily, Dalton and Canella (2003, p. 371) define governance as "the determination of the broad uses which organizational resources will be deployed and the resolution of conflicts among the myriad participants in organizations". Corporate Governance mechanisms aim at assuring to shareholders that managers will strive to achieve outcomes that are aligned with shareholders' interest (Shleifer \& Vishny, 1997; Williamson, 1996).

In a broad definition, according to Jensen (1993), there are four control forces operating on the corporation to resolve the problems caused by conflict of interest between managers and shareholders. They are: (i) legal, political and regulatory systems, (ii) product and factor markets, (iii) capital markets and (iv) internal control systems headed by the board of directors. The author suggests that while the first force is too blunt and cannot resolve properly inefficiencies generated by poor management, the second force is usually too late when disciplines the effects, as very often companies cannot be saved from an imminent failure. Therefore, the field of Corporate Governance focuses exclusively on the third and forth governance structures, namely internal and external mechanism to protect shareholders 'interest.

The evolution of an active market for corporate control has been accompanied by an increase in the sophistication and variety of managerial defense tactics against hostile suitors. Walsh and Seward (1990), by pointing out this phenomenon, have indirectly suggested that all the limitation of the current external governance structure, emphasizes the relevance of internal corporate governance protecting mechanisms.

In this context, internal governance mechanisms are the second set of tools that shareholders have at their disposal. Shleifer and Vishny (1997) point out that some internal governance structures are an effectively structured board, compensation packages that align interests and participation of institutional investors in the board. The authors advocate that the most important internal control mechanism is, however, the board of directors, arguing that it is central not only to the role of controlling managers but, also extremely relevant due to its knowledge pool and strategic orientation.

So far the main focus of studies of corporate governance in Brazil has been its relation to company's performance and valuation at the Brazilian stock-market (Silveira, Barros \& Famá, 2006; Oliveira Neto, Medeiros \& Queiroz, 2012; Rossoni \& Machado da Silva, 2013). 


\subsection{Board of Directors}

In order to understand some point of debate regarding the board of directors, it is useful to adopt Fama and Jensen (1983) decision process framework. Differently than entrepreneurial firms, in which decisions are very often taken by a limited number of people if not a single one, in modern corporations there is a complex decision process. As the authors suggest, it consists basically on four steps: (i) initiation, which refers to proposing resources utilization and structuring contracts; (ii) ratification, which refers to the choice of decisions to be implemented; (iii) implementation and (iv) monitoring, which refers to measuring the performance of the decision agents and implementing rewards.

Having this framework in mind, the relevant questions to be answered are: in which of the four steps should the board of directors take part? Should it focus on the most commented one of monitoring or should it go further and also participate in the initiation and ratification of strategies and decisions?

The authors (Fama \& Jensen, 1983) suggest that for an effective system for decision control, the management team should be focused on initiating and implementing, while board of directors or any third party control body - should allocate efforts to ratify decisions and monitor them. Additionally, Clark (1986) argues that it is still unrealistic to view directors as making a significant impact on business policy decisions. As he says, directors simply approve them and occasionally offer advice or raise probing questions. In the same line of reasoning, Westphal and Fredrickson (2001) believe that while the board of directors is mainly focused on the financial control - as their responsibility is to protect shareholders and assure their financial right - the strategic control is generally reserved for executives. Even though some strategic changes are influenced by the selection of a new CEO - and therefore the board would have greater influence determining the new strategic path - it is widely accepted that boards only ratify decision of managers and very rarely initiate an alteration on their own (Westphal, 1999).

Derived from this situation, many problems arise from the relationship of board of directors and top management team. Firstly, information asymmetry represents a crucial challenge that needs to be overcome in order to the board be able to perform both counseling and monitoring of the management team. Information asymmetry refers to the fact that boards typically possess far less information than CEOs (Nowak \& McCabe, 2003). Therefore, the quality of the information boards hold compared to the quality of information the top management possess can be seen a good predictor for determining the level of monitoring that the first is able to deploy when disciplining the latter. Additionally, given that advice seeking reduces information asymmetry and results in more informed boards (Westphal, 1999), one could assume that boards more engaged in strategic definition tasks could perform better both controlling task - as it has more information - and counseling, as it holds more firm specific knowledge.

In the agency theory, information is regarded as a commodity, in the way that it has a cost and can be purchased (Eisenhardt, 1989). However, as this is clearly not the case in real organizational situations, challenges related from information asymmetry are undeniable. Firstly, given that knowledge is costly to transfer and the whole comprehension of the company and aggregated information for effective decisions are not concentrated in one single person in modern organizations - differently than entrepreneur firms - it leads to ineffective firms' structure and strategic paths. Secondly, managers that are daily immersed in the firm's context will naturally have more information than board members, who participate less frequently. Hence, managers could deviate from the interests of the residual claimants without being easily noticed by the board members.

Bearing all in mind, the evolution of board's role in more strategic manners is noticeable. Initially, boards were widely perceived as passive, functioning only as rubber stamps of managerial choices (Bavly, 1985). Following a series of corporate bankruptcies in the mid 1970s, and intensifying international competition, the importance of the strategic contribution of boards was reasserted (Zahra \& Pearce, 1990).

From this evolution, some drawbacks should also be pointed out. As the board cooperates more closely with the top management team, there are risks associated with entrenchment, lacking independence to successfully monitor executives. Although the board of directors is the ultimate decision body, CEOs and top management team can find shortcuts to influence board members

The literature also points out that the board is an important tool to improve companies performance (Macus, 2008; Anderson, Melanson, \& Maly, 2007). Casto et al (2009), for example, has 
found that synergy between board of directors and top management team is able to generate strategic changes

\section{4 CEO Relative Power}

Corporate governance literature has concentrated much of attention in defining the relative CEO power (Nyberg et al, 2010), as it aims to understand the link between decreasing independence of the board to the firm's performance. In this context, some information is used when assessing the level of independence of the board. Following, four of them are discussed more deeply.

Outside directors refer to executives that are not involved in the daily operations of the company. It is widely agreed that boards with more independent directors have stronger monitoring capabilities (Weisbach, 1988; Borokhovic \& Parrino, 1996; Fama \& Jensen, 1983).

Fama and Jensen (1983) argue that because outside directors have incentives to develop reputation as experts in decision control, they are less likely to collude with internal managers and adopt decisions that deviate from the interest of the residual claimants. In this context, given that their human capital value will depend on the performance of the firms they participate in the board, they have incentives to behave properly. Hence, one could assume that boards composed with more outside directors will perform better monitoring and counseling functions.

However, some authors have tried to break this paradigm, by offering a number of explanations. Hart (1995) argues that given that outside directors do not have a significant financial interest in the company, and would have little to gain from increase in the firm's performance, they are less effective monitors than one would expect. Moreover, outside directors are busy people (Fich \& Shivdasanti, 2006) and consequentially do not have the necessary resources to devote to the focal company. Finally, outside directors may owe their position to the management team, and therefore would be highly influenced by the CEO's perspectives.

Zahra and Pearce (1990) point out four - similar - practical limitations that may hinder the strategic involvement of outside directors and, therefore, their perceived value relative to inside directors. Firstly, demands of their other professional responsibilities may make it difficult to devote the necessary amount of time. Second, the risk of interlocking - outside directors adopting a collusive behavior to protect some hidden interest - increases with the representation of more outside directors. Third, since the CEO still plays an important role selecting outside directors, they are not fully independent from the management team. Lastly, it has been observed that when directors face some conflicting view with the management team, they are more inclined to resign instead of confronting.

Westphal and Bednar (2005) approach the ineffectiveness of outside directors from the perspective of pluralistic ignorance. This phenomenon refers to the situation when even under conditions of low performance, there is a systematic tendency for outside directors to withhold their concerns about the firm and, consequentially, decreases the likelihood of initiating strategic changes in response to low performance. The independent variables, in order to explain pluralistic ignorance, are communication and social integration, both resulting from demographic homogeneity and dense friendship ties among group members. In that sense, it can be understood that having closer social proximity with other members is not always detrimental to the effectiveness of board of directors, but may mitigate the existence of pluralistic ignorance between them.

CEO duality occurs when the same person holds both the CEO and the board chairperson positions in a corporation (Finkelstein \& D'Aveni, 1994). The most commented aspect about this situation is that CEOs exert excessive influence on boards, what is referred as entrenched boards. It is widely accepted that the separation of the CEO and the chair of the board help to improve board monitoring effectiveness (Klein, 1998).

So far corporate governance literature in relation to control and performance has covered topics such as leadership structure inside/outside director (Dalton, Hitt, Certo, \& Dalton, 2007), board hierarchy (Huse, 2007; He \& Huang, 2011); and alignment of executive compensation (Aggarwal \& Samwick, 1999; Carpenter \& Sanders, 2002). This article moves forwards the discussing the effect stricter governance and financial performance in the Brazilian context. 


\section{Methods}

The research question of this paper is do Brazilian companies with a stricter governance control and monitoring system perform better than others? In order to answer this question 116 companies were assessed. From the 534 companies listed in the Stock Exchange of Sao Paulo Bovespa - 116 were selected due to their level of corporate governance. The title "Novo Mercado" refers to the superior level of governance level within companies listed in Bovespa, as they have to follow specific criteria to assure shareholders 'protection (BM\&F, 2011).

Some of the requirements of the title "Novo Mercado" are: equity composed exclusively by voting shares, board of directors composed by minimum five directors, being $20 \%$ independent directors, disclosure of financial statements on a quarterly basis according to an accounting standard, minimum $25 \%$ of the shares in the free float market, among others (BM\&F, 2011).

In order to assess the level of control the board of directors has over the management team, the 116 companies were assessed according to four parameters: percentage of independent directors (Weisbach, 1988; Borokhovic \& Parrino, 1996; Fama \& Jensen, 1983), the separation of chairman and CEO (Rechner \& Dalton, 1991), the adoption of contingent compensation (Westphal, 1999) and the percentage of institutional investors in the ownership breakdown (Finkelstein \& D'Aveni, 1994). All the data is public information and was acquired through investor relation websites.

After assessing the companies in respect to these four parameters, companies were scored with final amount of points, which measures the independence level between the top management team and the board of directors. In that way, the final board of directors' power relative to the CEOs is easily measured in one standardized variable. The financial return of each firm is measured as the Return on Assets (ROA), from information published in the latest quarterly earnings release in 2012.

The selection of ROA as the financial measure was based on the widely acceptance of this indicator as a short-term performance appraise (Finkelstein \& D'Aveni, 1994; Westphal, 1999; Westphal \& Zajac, 1994). Given that the expected return on assets is highly dependent on the industry that the company operates, the sample of 116 companies was also categorized by industries, being this information obtained by BM\&F classification. BM\&F categorizes companies by three levels: economic sector, subsector and segment. Therefore, the results analyses are explored from this perspective.

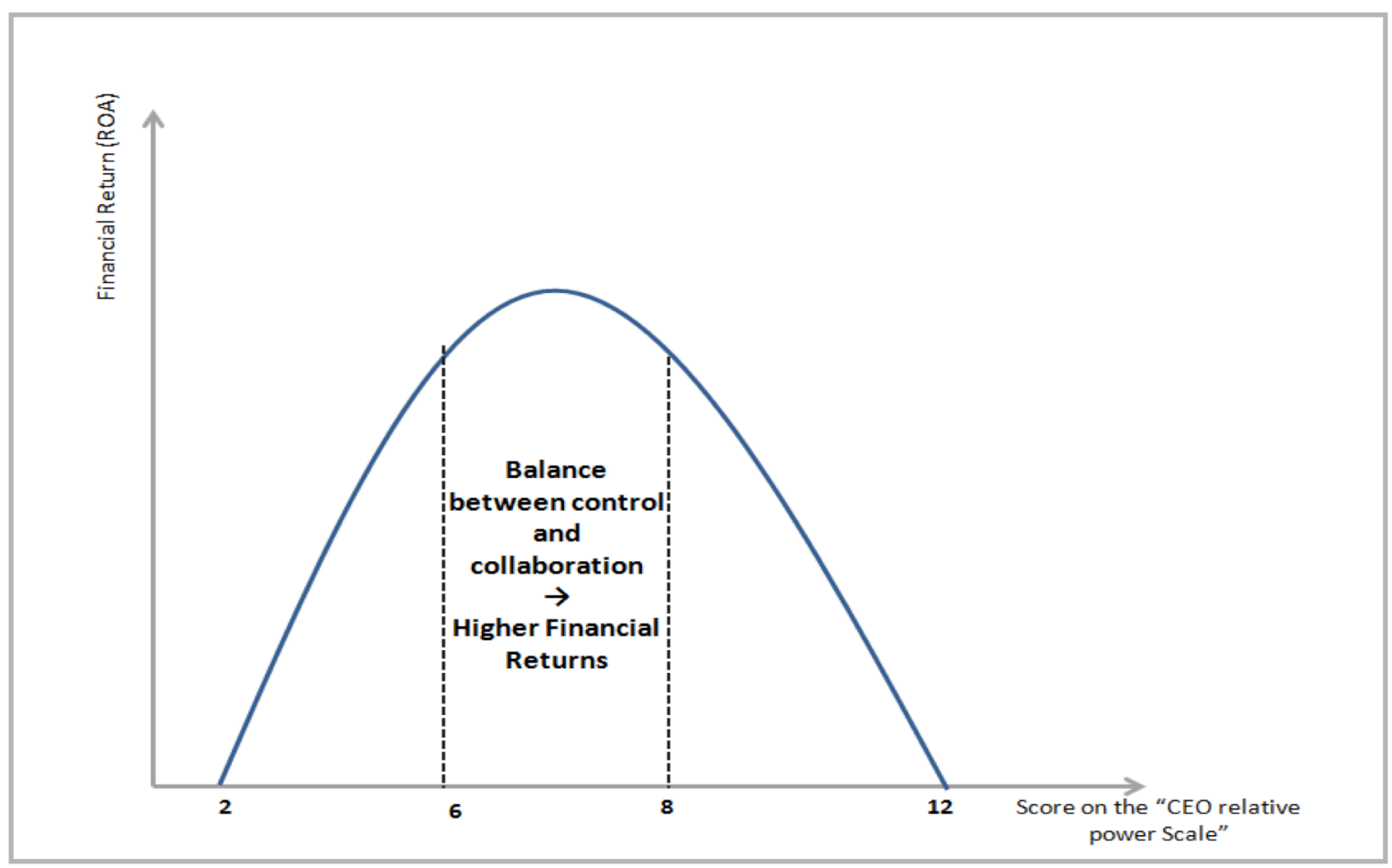

Figure 1 - Inverted curvilinear shape between control and financial return (ROA)

Note: Source: Elaborated by authors 
The aggregated score each company can be attributed is between 2 and 12 . In the scale, 2 represents the least independent board, while 12 refers to the case in which the board is highly independent from the top management team. Given that this paper argues that a balance between collaboration and control between board of directors and top management team leads to higher financial return, inverted curvilinear relationship logic is applied. On other words, the higher the synergy between board and top management team the higher the financial performance, balance between board of directors and top management team is our proxy for stricter control. Figure 1 summarizes this idea.

The curvilinear shape of the scale has been based on an article written by Golden and Zajac (2001), in which the authors advocate that the extremely divided conceptualization of boards as passive or active hide some nuances of the relationship between top management team and board of directors. In other words, depending on the current situation that a company faces at the moment, in respect to the level of monitoring and board strategic involvement, changes such as increasing outside directors and the tenure of the members may be beneficial or detrimental.

Parameters utilized were outside directors, CEO Duality, contingent compensation and institutional investor ownership. The scale for outside directors has been structured in the following manner. The title of "Novo Mercado" imposes that companies' board have at least $20 \%$ of independent outsiders. Therefore, there are 80 points to be distributed accordingly, referring to the percentage between $20 \%$ and $100 \%$. In that sense, aiming at providing the same level of relevance as the other parameters, the maximum points attributed will be 3 and the minimum one. The division is presented in table 1.

Table 1

Scale of Percentage of Outside Directors

\section{$\%$ of Outside Directors \\ Points}

$$
0-20 \%
$$

Less than minimum required for "Novo Mercado"

$21 \%-46 \%$

$47 \%-73 \%$

$74 \%-100 \%$
1

2

3

Note. Source: Elaborated by authors

The study of CEO duality - referring to the situation in which the chair of the board and the executive command are occupied by the same person - makes it apparent that it is not easy to simultaneously establish unity of command at the top and avoid CEO entrenchment (Finkelstein \& D'Aveni, 1994). Following previous work, this variable will be treated as a dichotomous. In that sense, it will be attributed zero point for the situation which the CEO is the chairman and 3 for the opposite situation (Rechner \& Dalton, 1991).

Contingent compensation refers to the share of compensation that depends upon the achievement of specific performance goals (Westphal, 1999). Although contingent compensation is likely to align interests between shareholders and top management team and, therefore, could be seen as an efficient mechanism to reduce agency problems, it also presents some drawbacks. Specifically, linking manager compensation too closely to firm wealth might lead risk avoiding behavior on the part of the agent (Westphal \& Zajac, 1994). Therefore, given this tricky situation of determining what is "too closely", this variable seems to fit the inverted curvilinear shape of the scale. Table 2 summarizes the score attributed to each company in respect to contingent compensation. It is important to note that answering according to this system, this parameter also has the same level of relevance, as the maximum is three points. 
Table 2

Scale for Contingent Compensation

\begin{tabular}{|l|c|c|}
\hline $\begin{array}{l}\text { Contingent Compensation } \\
\text { Does the company make use of }\end{array}$ & Yes & 1 \\
\hline $\begin{array}{l}\text { contingent compensation for the CEO? } \\
\text { Does the company make use of }\end{array}$ & No \\
\hline $\begin{array}{l}\text { contingent compensation for the } \\
\text { directors? }\end{array}$ & Yes \\
\hline $\begin{array}{l}\text { Does the company disclose the level } \\
\text { of contingent compensation in annual } \\
\text { reports or other communication }\end{array}$ & No & 0 \\
\hline \begin{tabular}{l} 
vehicle? \\
\hline
\end{tabular} & Yes \\
\hline
\end{tabular}

Note. Source: Elaborated by authors

The category of "Novo Mercado" demands that at least $25 \%$ of the shares are traded in the free float market. Therefore, there are 75 points, referring to $0 \%$ to $75 \%$ that can be divided into three equal clusters. In that sense, this parameter also has the same level of importance as the ones before, namely, maximum of three points. Table 3 presents this division for institutional investors.

Table 3

Scale Institutional Investor Ownership

\begin{tabular}{|c|c|}
\hline $\begin{array}{c}\text { \% of Institutional investor } \\
\text { ownership }\end{array}$ & Points \\
\hline Up to $25 \%$ & 1 \\
\hline $26 \%-50 \%$ & 2 \\
\hline $51 \%-75 \%$ & Less than minimum required by "Novo \\
\hline More than $75 \%$ & Mercado" \\
\hline
\end{tabular}

Note. Source: Elaborated by authors

Having scored the companies in respect to the described scale, analyses were performed. The first set of analysis assesses how much the CEO relative power score scale grasps the expected financial return of a company. In other words, two regression analyses are initially conducted, grounded in the developed scale of this paper: firstly, the individual score of each parameter and the financial return measured in terms of ROA; secondly, the CEO relative power score (aggregated score).

\section{Results and Analysis}

Table 4 comprises an extensive analysis of the results of the four measured parameters of CEO relative power. The percentage of independent outsiders already sends a clear message, as the vast 
majority of the companies - $83.6 \%$ - adopt between $21 \%$ and $46 \%$ of the outsiders. In that way, they only operate one level above the required percentage of $20 \%$ and fifteen percentile points, given that the overall average of independent outsiders is 35\%. From this initial understanding, it is possible to affirm that given the already strict rules imposed by the category "Novo Mercado", companies very rarely push beyond this level. In other words, they do not overemphasize corporate governance as a mechanism to further protect shareholders 'interest or increase the financial return, but they are rather shaped by the regulatory system.

Table 4

Overview CEO Relative Power - Per Parameter

\section{Overview CEO Relative Power}

\% Independent Oustsiders

\begin{tabular}{|c|c|c|}
\hline Range & No & $\%$ \\
\hline $21 \%-46 \%$ & 97 & $83.6 \%$ \\
\hline $47 \%-73 \%$ & 17 & $14.7 \%$ \\
\hline $74 \%-100 \%$ & 2 & $1.7 \%$ \\
\hline
\end{tabular}

CEO Duality

\begin{tabular}{|c|c|c|}
\hline Question & No & $\%$ \\
\hline No & 84 & $72.4 \%$ \\
\hline Yes & 32 & $27.6 \%$ \\
\hline
\end{tabular}

\section{Contingent Compensation}

\begin{tabular}{l} 
Question \\
Does the company make use of contingent compensation \\
for the CEO? \\
\hline Yes
\end{tabular}

\% Institutional Ownership

\begin{tabular}{|c|c|c|}
\hline Range & No & $\%$ \\
\hline Up to $25 \%$ & 5 & $4.3 \%$ \\
\hline $26 \%-50 \%$ & 26 & $22.4 \%$ \\
\hline $51-75 \%$ & 74 & $63.8 \%$ \\
\hline
\end{tabular}

Note. Source: Based on secondary data gathering elaborated by the authors.

In respect to the existence of CEO duality, almost three quarters of the companies do not hold a situation in which the CEO also performs the role of chairman of the board. The case of CEO duality most commonly happens in partially owned family companies, such as Arezzo, Cia Hering and JHSF Participações. The literature proposes that CEO duality can be beneficial when the company is facing a difficult financial situation, as this sends a message to the market of who is in charge of the "ship" 
(Finkelstein \& D'Aveni, 1994). However, at this point it is important to note that the average return on assets performed by the cluster of companies that hold a CEO duality is $6.22 \%$, while the overall average is $6.36 \%$. Therefore, this argumentation does not seem to apply here.

Contingent compensation is an additional mechanism to align top management team interests and shareholders' interests. The sample illustrates that this tool is widely applied for both CEOs and directors: $60 \%$ and $56 \%$, respectively, of the companies use contingent compensation for chief executive officers and directors. In respect to disclosing the level of contingent compensation usually published in annual reports and in the ownership breakdown, in cases in which the top management team and directors hold a part of the shares $-70 \%$ of the companies adopt this practice.

A more interesting analysis of the adoption of contingent compensation occurs when aggregating the answer of the three questions, so it is possible to observe how companies behave simultaneously to these three matters. In that sense, almost one quarter of the sample do not adopt any of these practices, namely, using contingent compensation for CEOs, directors and disclosing the level of contingent compensation adopted. Table 4 illustrates that $24 \%$ of the companies scored zero points. One level up, there are $18 \%$ of the companies that have been assessed with one point, which means that out of the three potential practices from contingent compensation, they adopt one of them. The number of companies with two points in this parameter calls attention: only $6 \%$ of sample has been scored two points, which implies that a normal distribution cannot be observed in this parameter. Lastly, slightly over the majority of the companies scored 3 points, which means that they adopt contingent compensation for CEOs, directors and also disclose the level of compensation applied in each case. It is noteworthy that three quarters of the sample scored in the extremes of the scale - either zero or three points - triggering the question of whether companies perceive the value of contingent compensation only when the mechanism is fully put in practice.

Many companies adopt contingent compensation practices seeking for legitimacy, rather than considering technical improvements (Zucker, 1977). In that way, bearing in mind the two extremes that companies operate (either scoring zero or three points in this parameter), it seems that this Zucker's theory can be observed.

It has been expressed that contingent compensation - especially in the form of long term incentive plan (LTIP) - is more efficient and should be further applied when the financial performance is different than the expected one (Beatty $\&$ Zajac, 1994). In that sense, we could assume that the financial return for the cluster of companies that scored three points in this parameter is lower than the financial return of companies that score zero points. It is important to bear in mind that given some sample limitation - the amount of companies that scored three is more than the double than the amount of companies that scored zero - statically it is not possible perform a test to prove this hypothesis.

Lastly, the parameter of percentage of institutional investor indicates that $64 \%$ of the sample holds ownership structures that are on the upper limit allowed by Bovespa. According to “Novo Mercado" rules, companies are required to have at least $25 \%$ of the shares in the free floating market. This requirement is based on the logic that liquidity is highly important to stock exchanges, as it attracts more capital and investors, boosting the country's economy (BM\&F, 2011). The average of the cluster of companies that scored three in this parameter is $65 \%$, while the overall average of the sample is $61 \%$. On the other extreme, it is noteworthy that less than $5 \%$ of the companies adopt a less concentrated capital structure, in the case of having less than $25 \%$ of the capital represented by institutional investors.

From observing Table 5 a couple of comments can be drawn. Firstly, despite the significant increase in the result of Multiple R, it is still low (35.55\%) in statistics terms. Another important point to mention is that among the thirteen variables included in this regression (ten dummy variables and three continuous variables), only two presented a p-value lower than 10\%, the significance level adopted to test the hypothesis. In this sense, only the variables "board composed by $20 \%$ of independent directors" and the "percentage of institutional investor" were meaningful in statistics terms to explain the financial return.

It is important to highlight that two variables (percentage of outside directors and percentage of institutional investors) have a p-value lower than $10 \%$, which indicates that they are significant when explaining the financial return of the selected sample. Moreover, both of the variables have a negative coefficient with the dependent variable - financial return measured in terms of ROA - which partly corroborates the research question of this paper. 
Table 5

Regression Analysis with all Dummy Variables

\begin{tabular}{|c|c|c|c|c|c|c|c|c|}
\hline \multicolumn{9}{|c|}{ Regression Analysis - With all Dummy Variables } \\
\hline \multicolumn{2}{|l|}{ Regression Statistics } & & & & & & & \\
\hline Multiple R & $35.5524 \%$ & & & & & & & \\
\hline R Square & $12.6397 \%$ & & & & & & & \\
\hline Adjusted R Square & $1.506 \%$ & & & & & & & \\
\hline Standard Error & 0.0902206 & & & & & & & \\
\hline Observations & 116 & & & & & & & \\
\hline \multicolumn{6}{|c|}{ ANOVA } & & & \\
\hline & df & Ss & MS & $\mathbf{F}$ & Significance $\mathrm{F}$ & & & \\
\hline Regression & 13 & 0.120125386 & 0.009240414 & 1.135219965 & 0.338972134 & & & \\
\hline Residual & 102 & 0.830255182 & 0.008139757 & & & & & \\
\hline \multirow[t]{2}{*}{ Total } & 115 & 0.950380568 & & & & & & \\
\hline & Coefficients & Standard Error & t Stat & P-value & Lower $95 \%$ & Upper $95 \%$ & Lower $95,0 \%$ & Upper $95,0 \%$ \\
\hline Intercept & 0.145 & 0.134 & 1.076 & $28.4 \%$ & -0.122 & 0.411 & -0.122 & 0.411 \\
\hline LN(Total Assets) & 0.004 & 0.008 & 0.447 & $65.6 \%$ & -0.012 & 0.020 & -0.012 & 0.020 \\
\hline$\%$ Independentes & -0.104 & 0.135 & -0.773 & $44.1 \%$ & -0.371 & 0.163 & -0.371 & 0.163 \\
\hline Board composed by 5 directors? & -0.052 & 0.032 & -1.647 & $10.3 \%$ & -0.114 & 0.011 & -0.114 & 0.011 \\
\hline Board composed by $20 \%$ outside directors? & 0.078 & 0.040 & 1.945 & $5.5 \%$ & -0.002 & 0.158 & -0.002 & 0.158 \\
\hline$\%$ outsiders $>\%$ insiders & 0.018 & 0.048 & 0.372 & $71.1 \%$ & -0.078 & 0.113 & -0.078 & 0.113 \\
\hline CEO $=$ Chairman & 0.012 & 0.021 & 0.563 & $57.4 \%$ & -0.029 & 0.052 & -0.029 & 0.052 \\
\hline Contingent Compensation CEO & 0.007 & 0.033 & 0.211 & $83.3 \%$ & -0.059 & 0.073 & -0.059 & 0.073 \\
\hline Contingent Compensation Directors & -0.029 & 0.036 & -0.801 & $42.5 \%$ & -0.102 & 0.043 & -0.102 & 0.043 \\
\hline Disclose Compensation Scheme & -0.009 & 0.025 & -0.367 & $71.5 \%$ & -0.060 & 0.041 & -0.060 & 0.041 \\
\hline Institutional Investors & -0.156 & 0.073 & -2.146 & $3.4 \%$ & -0.300 & -0.012 & -0.300 & -0.012 \\
\hline Most represented institutional investor & -0.030 & 0.095 & -0.312 & $75.6 \%$ & -0.218 & 0.159 & -0.218 & 0.159 \\
\hline Only $25 \%$ are in the free float? & 0.027 & 0.029 & 0.931 & $35.4 \%$ & -0.030 & 0.084 & -0.030 & 0.084 \\
\hline More than $50 \%$ concentrated in one institutional investor & 0.031 & 0.037 & 0.853 & $39.6 \%$ & -0.041 & 0.104 & -0.041 & 0.104 \\
\hline
\end{tabular}

Note. Source: Elaborated by authors

In other words, counter affirming what the literature very often portraits as being self-evident stricter governance leads to higher performance - this paper has provided evidences to believe that the increase in the formal governance structure trough outside directors in the board and ownership by institutional investor might actually led to worse performance. Although only two of the previously selected four parameters have proven to be significant and with negative coefficient with financial return, this paper can be considered a first attempt to demystify the widely accepted governance superiority paradigm, in the sense that stricter governance control and performance are not closely related.

\section{Conclusions}

This paper aimed at examining the relationship between governance structures perceived to be stricter - in respect to the level of control and monitor - and the financial return of the companies. The underlying reasoning is that not necessarily more sophisticated governance structures in regard to control will lead to higher financial return, given that some other aspects, such as collaboration and trust among the top management team and the board of directors although crucial, are still neglected (Zahra \& Pearce, 1990).

The percentage of independent outsiders sends a clear message, as the vast majority of the companies - $83.6 \%$ - adopt between $21 \%$ and $46 \%$ of the outsiders. In that way, they only operate one level above the required percentage of $20 \%$. Therefore, it is possible to affirm that given the already strict rules imposed by the category "Novo Mercado", companies very rarely push beyond this level and are rather shaped by the regulatory system.

In respect to the existence of CEO duality, almost three quarters of the companies do not hold a situation in which the CEO also performs the role of chairman of the board. The literature proposes that CEO duality can be beneficial when the company is facing a difficult financial situation, as this sends a message to the market of who is in charge of the "ship" (Finkelstein \& D'Aveni, 1994). However, as it was presented, given that the average return on assets performed by the cluster of companies that hold a CEO duality is $6.22 \%$, while the overall average is $6.36 \%$, this argumentation does not seem to apply here.

The observed trend in contingent compensation also has some theoretical background support. It was noticeable how the majority of the companies scored either the maximum of minimum points, 
which might refer to the fact that when engaged in this type of practice, companies are also seeking for legitimacy, and not only focusing on technical improvements (Zucker, 1977).

Finally, the percentage of institutional investor in the ownership breakdown showed that the sample average was $61 \%$, while the maximum allowed by "Novo Mercado" rules is $75 \%$.

Given the problem of multicollinearity, the final multiple R obtained is still statistically low, $28.44 \%$, which implies that the combination of the variables are still not enough to translate the complex reality of organizations. As mentioned earlier, some extremely important aspects of governance structures, such as selection of new CEO (Westphal, 1999); CEO tenure and directors tenure (Zahra \& Pearce, 1990); demographic distance (Westphal \& Bednar, 2005); and amount and frequency of committee were not included in the analysis, which might the reason to low multiple R.

Nonetheless, an important finding can be taken from this paper: two variables (percentage of outside directors and percentage of institutional investor ownership) are significant in the regression, with p-value lower than $10 \%$. In other words, counter affirming what the literature very often portraits as being self-evident - stricter governance leads to higher performance - this paper has provided evidences to believe that the increase in the formal governance structure trough outside directors in the board and ownership by institutional investor might actually lead to worse performance. Although only two of the previously selected four parameters have proven to be significant and with negative coefficient with financial return, this paper can be considered a first attempt to demystify the widely accepted governance superiority paradigm, in the sense that stricter governance control and performance do not follow the behavior exhaustively described in the literature. The reason why outside directors in the board and ownership by institutional investor might actually lead to worse performance is not clear. Future studies could try to understand the reasons for this paradox specially in the Brazilian setting.

\section{Notes}

1. Authors wish to thanks two anonymous reviewers.

\section{References}

Aggarwal, R. K., \& Samwick, A. A. (1999). The other side of the trade-off: The impact of risk on executive compensation. Journal of Political Economy, (107), 65-104.

Anderson, D. W., Melanson, S. J., \& Maly, J. (2007). The evolution of corporate overnance: Power redistribution brings board to life. Corporate Governance: An International Review, (15), 780-797.

Bavly, D. (1985). What is board good for? Long Range Planning, 19(3), 20-26.

Beatty, R., \& Zajac, E. (1994). Managerial incentives, monitoring, and risk bearing: a study of executive compensation, ownership and board structure in initial public offering. Administrative Quarterly Science, 39(2), 313-335.

BM\&F. (2011). Perguntas Frequentes BM\&F. Retrieved May 21, 2012, from http://www.bmfbovespa.com.br/empresas/pages/empresas_perguntas-frequentes.asp\#3

Borokhovic, K., \& Parrino, R. (1996). Outside directors and CEO selection. Journal of Finacial and Quantitative Analysis, (31), 337-355.

Cai, J., Liu, Y., \& Qian, Y. (2002). Information asymmetry and corporate governance. Academy of Management Review, (90), 430-467.

Carpenter, M. A., \& Sanders, W. M. G. (2002). Top management team compensation: The missing link between CEO pay and firm performance? Strategic Management Journal, (23), 367-375.

Caixe, D. F., \& Krauter, E. (2013). A influência da estrutura de propriedade e controle sobre o valor de mercado corporativo no Brasil. Revista Contabilidade \& Finanças, 24(62), 142-153.

Castro, C. B., De La Concha, M. D., Gravel, J. V. \& Periñan, M. M. V. (2009), Does the Team Leverage the Board's Decisions?. Corporate Governance: An International Review, (17), 744-761.

Claessens, S., \& Burcin Y. (2013). Corporate Governance in Emerging Markets: A Survey. Emerging Markets Review, (15), 1-33.

Clark, R. C. (1986). Corporate Law. Boston: Little Brown.

Dalton, D. R., Hitt, M. A., Certo, S. T., \& Dalton, C. M. (2007). The fundamental agency problem and 
its mitigation. In J. P. Walsh \& A. P. Brief (Eds.), Academy of Management Annals, (pp. 1-64). New York: Erlbaum.

Daily, C. M., Dalton, D. R., \& Canella, A. (2003). Corporate governance: decades of dialogue and data. Academy of Management Review, (28), 371-382.

Eisenhardt, K. (1989). Agency theory: an assessment and review. Academy of Management Review, (14), 54-74.

Fama, E. (Apr. de 1980). Agency Problems and the Theory of the Firm. Journal of Political Economy, (88), 288-307.

Fama, E., \& Jensen, M. (1983). Separation of Ownership and Control. Journal of Law and Economics, (26), 301-325.

Fich, E., \& Shivdasanti, A. (2006). Are busy boards effective monitors? The journal of Finance, 71(2), 689-724.

Finkelstein, S., \& D'Aveni, R. (1994). CEO duality as a double-edged sword: how boards of directors balance entrenchment avoidance and unity of command. The Academy of Management Journal, 37(5), 1079-1108.

Hart, O. (1995). Corporate governance: some theory and implications. The Economic Journal, 105: 678-689.

He, J., \& Huang, Z. (2011) Board Informal Hierarchy and Firm Financial Performance: Exploring a Tacit Structure Guiding Boardroom Interactions. Academy of Management Journal, 54 (6): 11191139.

Huse, M. (2007). Boards, governance and value creation. Cambridge, U.K: Cambridge University Press.

Jensen, M. C. (1993). The modern industrial revolution: exit, and the failure of internal control systems. The journal of Finance, (48), 831-880.

Jensen, M., \& Meckling, W. (1976). Theory of the firm: managerial behaviorm agency costs and owership structure. Journal of Financial Economics, (3), 305-360.

Klein. (1998). Firm performance and board committee structure. Jounal of Law \& Economics, (41), 275-303.

Lan, L. L. \& Heracleous, L. (2010) Rethinking agency theory: the view from law. Academy of Management Review, 35(2), 294-314.

Langevoort, D. C. (2001). The human nature of corporate boards: law, norms and the unintended consequences of independence and accountability. Georgetown Law Journal, (89), 797- 832.

Marcel, J. J. \& Cowen, A. P. (2014), Cleaning house or jumping ship? Understanding board upheaval following financial fraud. Strategic Management Journal 35: 926-937.

Macus, M. 2008. Board capability. International Studies of Management and Organization, 38: 98116.

Nowak, M. J., \& McCabe, M. (2003). Information costs and the role of the indepedent director. Coporate Governance, 11: 300-307.

Nyberg, A. J., Fulmer, I.S., Gerhart, B., \& Carpenter, M.A. (2010). Agency Theory Revisited: CEO Return and Shareholder Interest Alignment. Academy of Management Journal, 53(5): 1029-1049.

Okimura, R. T., Silveira, A. M. da, \& Rocha, K. C. (2007). Estrutura de propriedade e desempenho corporativo no Brasil. RAC-Eletrônica, 1(1): 119-135.

Oliveira Neto.J.C.C., Medeiros, O.R. \& Queiroz, T. B. (2012) Governança Corporativa e Velocidade de Incorporação de Informações: Lead-Lag entre o IGC e o IBrX. Revista Brasileira de Finanças, 10(1), 150-172

Pinto, Marcos Barbosa, \& Leal, Ricardo Pereira Câmara. (2013). Ownership concentration, top management and board compensation. Revista de Administração Contemporânea, 17(3): 304-324.

Rechner, P., \& Dalton, D. (1991). CEO duality and organizational performance: a longitudinal analysis. Strategic Management Journal, 12: 155-160.

Ross, S. (1973). The economic theory of agency: the principal's problem. American Economic 
Review, 63: 134-139.

Rossoni, L, \& Machado-da-Silva, Clovis L.. (2013). Legitimidade, governança corporativa e desempenho: análise das empresas da BM\&F Bovespa. Revista de Administração de Empresas, 53(3): 272-289.

Silveira, A. M., Barros, L.A.B.C.,Famá,R.,(2006). Atributos Corporativos, Qualidade da Governança Corporativa e Valor das Companhias Abertas no Brasil. Revista Brasileira de Finanças 4(1): 1-30

Saltaji, I. M. F. (2013) Corporate Governance

Agency Theory How to Control Agency Costs. Internal Auditing \& Risk Management, 4(32): 47-60

Shavell, S. (1979). Risk sharing and incentives in the principal and agent relationship. Bell Economic Journal, 10: 55-73.

Shleifer, A., \& Vishny, R. W. (1997). A survey of Corporate Governance. The Journal of Finance, 52: 737-783.

Walsh, J. P., \& Seward, J. K. (1990). On the efficiency of internal and external corporate control mechanism. The Academy of Management Review, 15(3): 421-458.

Williamson, O. E. The Mechanisms of Governance. New York: Oxford UP, 1996

Weisbach, M. S. (1988). Outside directors and CEO turnover. Journal of Financial Economics, 20: 431-460.

Westphal, J. D. (1999). Collaboration in the Boardroom: Behavioral and Performance Consequences of CEO-Board Social Ties. The Academy of Management Journal, 17: 7-24.

Westphal, J. D., \& Bednar, M. K. (2005). Pluralistic Ignorance in Corporate Boards and Firms'strategic Persitance in Reponse to Low Firm Performance. Administrative Science Quarterly, 95: 262-298.

Westphal, J., \& Fredrickson, J. (2001). Who directs strategic change? Director experience, the selection of new CEOs and change in corporate strategy. Strategic Management Journal, 22: 11131137.

Westphal, J., \& Zajac, E. (1994). Substance and symbolism in CEO's long term incentive plan. Administrative Science Quarterly, 39(3): 67-390.

Wilson, R. (1968). On the theory of syndicates. Econometrica, 36(1): 119-132.

Zahra, S., \& Pearce, J. (1990). Determinants of board directors' strategic involvement. Long Range Planning, 8(2): 164-173.

Zucker, L. G. (1977). The role of institutionalization in cultural persistance. American Sociological Review, 42: 727-743. 